\title{
The impact of nitrogen and phosphorous limitation on the estimated terrestrial carbon balance and warming of land use change over the last $156 \mathrm{yr}$
}

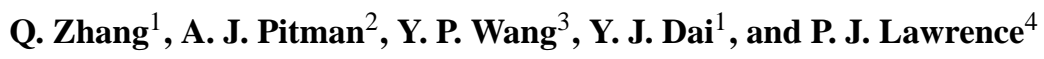 \\ ${ }^{1}$ College of Global Change and Earth System Science, Beijing Normal University, Beijing 100875, China \\ ${ }^{2}$ ARC Centre of Excellence for Climate System Science and Climate Change Research Centre, University of New South \\ Wales, Sydney 2052, Australia \\ ${ }^{3}$ CSIRO Marine and Atmospheric Research, PMB \#1, Aspendale, Vic 3195, Australia \\ ${ }^{4}$ National Centre for Atmospheric Research, Boulder, Colorado, USA \\ Correspondence to: Q. Zhang (qian.zhang@ bnu.edu.cn)
}

Received: 12 April 2013 - Published in Earth Syst. Dynam. Discuss.: 8 May 2013

Revised: 25 July 2013 - Accepted: 7 August 2013 - Published: 16 September 2013

\begin{abstract}
We examine the impact of land use and land cover change (LULCC) over the period from 1850 to 2005 using an Earth system model that incorporates nitrogen and phosphorous limitation on the terrestrial carbon cycle. We compare the estimated $\mathrm{CO}_{2}$ emissions and warming from land use change in a carbon-only version of the model with those from simulations, including nitrogen and phosphorous limitation. If we omit nutrients, our results suggest LULCC cools on the global average by about $0.1^{\circ} \mathrm{C}$. Including nutrients reduces this cooling to $\sim 0.05^{\circ} \mathrm{C}$. Our results also suggest LULCC has a major impact on total land carbon over the period 1850-2005. In carbon-only simulations, the inclusion of LULCC decreases the total additional land carbon stored in 2005 from around $210 \mathrm{Pg} \mathrm{C}$ to $85 \mathrm{Pg} \mathrm{C}$. Including nitrogen and phosphorous limitation also decreases the scale of the terrestrial carbon sink to $80 \mathrm{Pg} \mathrm{C}$. Shown as corresponding fluxes, adding LULCC on top of the nutrient-limited simulations changes the sign of the terrestrial carbon flux from a sink to a source $(12 \mathrm{PgC})$. The $\mathrm{CO}_{2}$ emission from LULCC from 1850 to 2005 is estimated to be $130 \mathrm{PgC}$ for carbon only simulation, or $97 \mathrm{PgC}$ if nutrient limitation is accounted for in our model. The difference between these two estimates of $\mathrm{CO}_{2}$ emissions from LULCC largely results from the weaker response of photosynthesis to increased $\mathrm{CO}_{2}$ and smaller carbon pool sizes, and therefore lower carbon loss from plant and wood product carbon pools under nutrient
\end{abstract}

limitation. We suggest that nutrient limitation should be accounted for in simulating the effects of LULCC on the past climate and on the past and future carbon budget.

\section{Introduction}

Human activity has modified $42-68 \%$ of the terrestrial surface via deforestation, reforestation, clearing for crops, pasture and urban settlements (Hurtt et al., 2006). Land use and land cover change (LULCC) is concentrated in regions such as eastern North America, Europe, India and China (Pielke et al., 2011). There is extensive literature pointing to significant impacts of these changes on regional temperature (Bonan, 1997; Gallo et al., 1999; Zhou et al., 2004; Lobell et al., 2008), temperature extremes (Avila et al., 2012; Pitman et al., 2012), rainfall (Niyogi et al., 2010; Pielke et al., 2011) and in some regions of intensive LULCC perhaps rainfall extremes (Pitman et al., 2012). Most of these studies have focused on the biogeophysical impacts of LULCC. These include changes in albedo that affects the net radiation available to drive the surface energy balance. LULCC also modifies the leaf area index, root depth, stomatal conductance and aerodynamic roughness length (Bonan, 2008) which combine to change the efficiency of water transfer from within the soil, through the plants and into the atmosphere via the stomata. 
This affects the partitioning of net radiation between sensible and latent heat fluxes (Bonan, 2008; de Noblet-Ducoudré et al., 2012; Boisier et al., 2012), which in turn can affect air temperature and the larger-scale climate (Feddema et al., 2005; Findell et al., 2007, 2009; Pitman et al., 2009; de Noblet-Ducoudré et al., 2012).

In addition to the biogeophysical impacts of LULCC, changing the nature of the surface also has a major impact on terrestrial biogeochemical cycles (Arneth et al., 2010; Levis, 2010; Houghton et al., 2012). If forests are replaced by crops or pasture, the soil carbon is reduced by $25-30 \%$ as a result of cultivation (Houghton and Goodale, 2004). The effect of ecosystem carbon balance will depend on the total ecosystem carbon before the land use change occurs, net primary productivity (NPP) of the crop or pasture and the rate of ecosystem carbon change after land use change. In addition, increases in atmospheric $\mathrm{CO}_{2}$ likely stimulates photosynthesis (Field et al., 1995) although nutrient limitation by nitrogen $(\mathrm{N})$ and phosphorous $(\mathrm{P})$ moderate this fertilization effect (Vitousek et al., 2010). The interactions between $\mathrm{CO}_{2}$ induced climate change and the terrestrial carbon balance, and the feedbacks associated with the response by the surface via $\mathrm{CO}_{2}$ emissions to climate change are extremely complex and uncertain (Friedlingstein et al., 2006) and LULCC is superimposed onto these interactions. As noted by Arneth et al. (2010), examining how LULCC interacts with biogeochemical cycling is a research priority.

The biogeochemical effects of LULCC in terms of land use emissions have been investigated previously within several climate models (e.g. Pongratz et al., 2009, 2011; Shevliakova et al., 2009). Carbon emissions from LULCC dampen biogeophysical cooling in some studies (Brovkin et al., 2004; Bala et al., 2007). In other studies, LULCCinduced cooling can be changed to warming once the terrestrial carbon feedback is included (Sitch et al., 2005; Pongratz et al., 2010). Recent studies in the Global Carbon Project suggest that LULCC nearly offsets the entire land sink from reforestation and $\mathrm{CO}_{2}$ fertilization since the preindustrial period (Canadell et al., 2007; Le Quéré et al., 2009). There are, however, large uncertainties in the magnitude of carbon loss linked to LULCC (Denman et al., 2007). Estimates of the scale of $\mathrm{CO}_{2}$ emission from LULCC between 1850 and 2000 vary from 44 to $150 \mathrm{Pg} \mathrm{C}$ (Houghton, 2008; Arora and Boer, 2010). A recent inter-comparison study reported carbon emissions due to LULCC for the 1990s had a range of $0.75-1.50 \mathrm{PgC} \mathrm{yr}^{-1}$, with a median value of $1.1 \mathrm{Pg} \mathrm{C} \mathrm{yr}^{-1}$ based on 13 model estimates (Houghton et al., 2012).

One weakness of existing studies of the impact of LULCC on biogeochemical cycles is the lack of the inclusion of nutrients. $\mathrm{N}$ limitation reduces the net carbon uptake by the global land biosphere by $37 \%$ to $74 \%$ from the preindustrial through to 2100 in some modeling studies (Thornton et al., 2007; Sokolov et al., 2008; Zaehle et al., 2010). Zhang et al. (2011) has also included $P$ to demonstrate regionally specific impacts over North America, Eurasia, China and
Australia. These are, of course, regions of extensive LULCC. Only a few current models incorporate LULCC and N cycle (Yang et al., 2010; Lawrence et al., 2012), and none includes phosphorus cycle. Here, we assess the impact of LULCC on terrestrial biogeochemical cycles in an Earth system model that includes LULCC, $\mathrm{N}$ and $\mathrm{P}$ cycles. We examine, in particular, the impact of LULCC from 1850 through to 2005 with a carbon-only version of our Earth system model and a version including $\mathrm{N}$ and $\mathrm{P}$ cycles on land biosphere. Our aim is to determine whether including nutrient substantially affects the global-scale impact of LULCC on the terrestrial carbon budget.

\section{Methods}

\subsection{Model description}

We used the CSIRO Mk3L (Phipps et al., 2011) coupled with a land surface model including carbon, nitrogen and phosphorous cycles, CABLE (Wang et al., 2010, 2011). Mk3L is a relatively low-resolution but computationally efficient general circulation model developed for studies of climate on centennial to millennial timescales (Phipps et al., 2011). The atmospheric component has a horizontal resolution of $5.6^{\circ}$ by $3.2^{\circ}$ and 18 levels in the vertical. CABLE performs well in comparison to other land surface models (LSMs) in simulating latent and sensible heat as well as $\mathrm{CO}_{2}$ fluxes at the site scale (Abramowitz et al., 2007, 2008; Wang et al., 2011). An earlier version was used in the Land Use Change IDentification of robust impacts (LUCID) project (Pitman et al., 2009; de Noblet-Ducoudre et al., 2012). Mao et al. (2011) documents the performance of Mk3L coupled to CABLE, which provides strong evidence that the coupled model produces a reasonable large-scale climatology. The version of CABLE used here includes the biogeochemical model CASA-CNP (Wang et al., 2010). CASA-CNP simulates dynamics of carbon, nitrogen and phosphorus in plant and soil. The coupled Earth system model has recently been used to explore the dependence of terrestrial carbon uptake due to $\mathrm{N}$ and $\mathrm{P}$ limitation through the 20th century without land cover change (Zhang et al., 2011).

\section{Data and experimental design}

The interpretation of the Coupled Model Intercomparison Project (CMIP-5, Taylor et al., 2012) land cover trajectories by Lawrence et al. (2012) for the period 1850-2005 is used to provide the change in area fractions of different plant functional type (PFT) within a land cell as a function of time compatible for CABLE. Figure 1 shows the pattern of changes in (a) forests, (b) grass, and (c) crops. In general, a pattern of forest reduction is clear, in particular over eastern North America, Europe and SE Asia. Grasslands have also been reduced in similar regions; though note an increase 

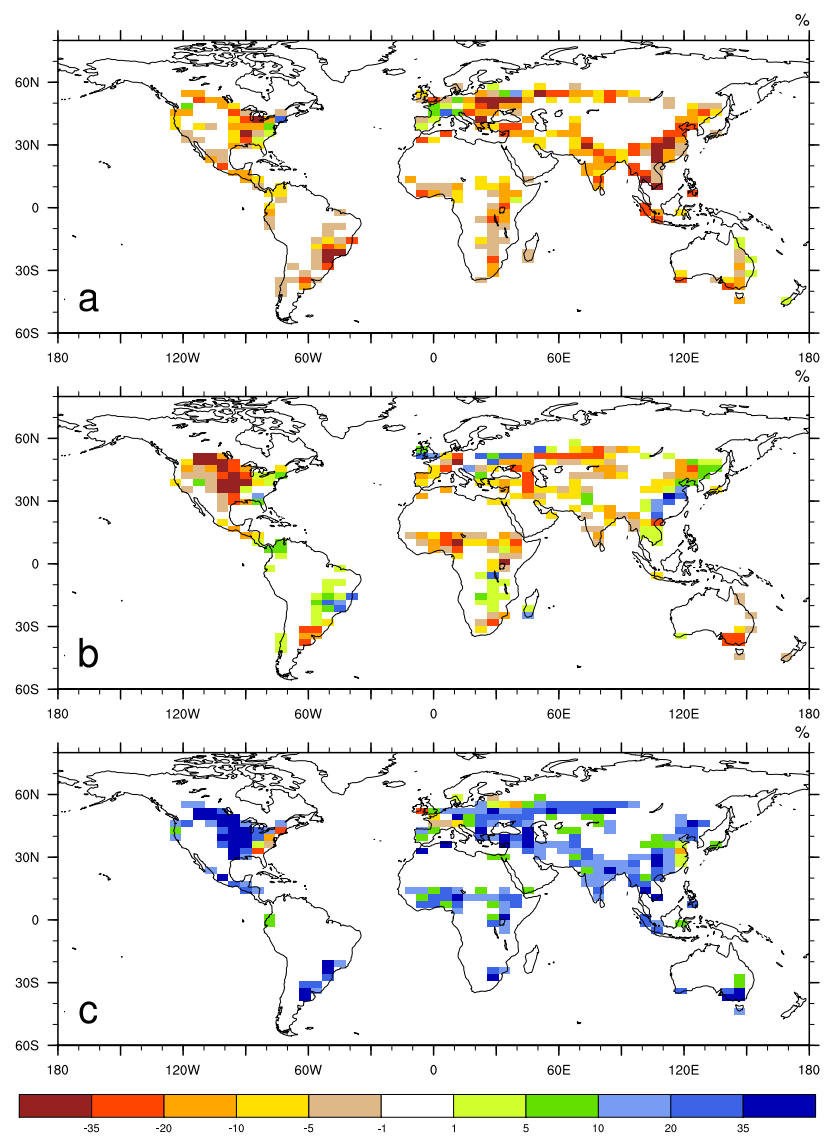

Fig. 1. Fractional changes in coverage of (a) woody, (b) grass, and (c) crop plant functional types for the period 1850-2005.

in grasslands in eastern South America coincident with decrease in forests. In most regions of the Northern Hemisphere, the forest removal has resulted in increased croplands (Fig. 1c). The scale of these changes, according to the CMIP5 experimental protocols are a reduction in total forest area from about $54 \times 10^{6} \mathrm{~km}^{2}$ in 1850 to about $47 \times 10^{6} \mathrm{~km}^{2}$ in 2005. Grasslands were also reduced from about $39 \times 10^{6} \mathrm{~km}^{2}$ in 1850 to about $36 \times 10^{6} \mathrm{~km}^{2}$ in 2005 . To balance these net reductions, croplands increased from about $4 \times 10^{6} \mathrm{~km}^{2}$ in 1850 to about $14 \times 10^{6} \mathrm{~km}^{2}$ in 2005 (Fig. 2).

In this study, the atmosphere model was forced by $\mathrm{CO}_{2}$ from CMIP-5 database for 1850-2005 (Meinshausen et al., 2011). The ocean is prescribed using monthly sea surface temperatures (SSTs) simulated by CSIRO-Mk3.6 (Rotstayn et al., 2010, 2012) for the CMIP-5 experiments associated with the same CMIP-5 $\mathrm{CO}_{2}$ for the same period. For model spin-up, we ran Mk3L with recycled SSTs for 1850-1879 to stable states for the carbon cycle only (C-only), carbon nitrogen and phosphorous cycles (CNP) cases under conditions of $\mathrm{CO}_{2}$ and land cover in $1850.200 \mathrm{yr}$ preindustrial control simulations under spin-up conditions were then performed before forward model integration. An ensemble of three historical (1850-2005) simulations are initialized at $10 \mathrm{yr}$ intervals from the last $30 \mathrm{yr}$ of $200 \mathrm{yr}$ control simulation under the preindustrial condition for each of the C-only and CNP cases.

To evaluate the effects of land use change on terrestrial carbon balance, we undertook two sets of experiments started from the same initial states. In the "LUC" experiment, the model was run using the land cover change and $\mathrm{CO}_{2}$ data. The land model was set up to run carbon cycle only (LUCC) and carbon, nitrogen and phosphorous cycle (LUC-CNP) cases for each LULCC ensemble simulations. In the "CTL" experiment, the same simulations were run except the vegetation distribution, which was kept constant as the one in 1850 for the whole 1850-2005 period. Atmospheric $\mathrm{CO}_{2}$ was prescribed using the CMIP-5 input to vary over time from 1850 to 2005 . We used the spatially explicit estimates of $\mathrm{N}$ deposition for the 1990s (Dentener, 2006) and P deposition map from Mahowald et al. (2008) over the simulation period because of the relatively small effects of the changes in $\mathrm{N}$ or $\mathrm{P}$ deposition on global land carbon balance over the last $150 \mathrm{yr}$ (Mahowald et al., 2008; Zaehle et al., 2010) and possible complication in interpreting our simulation results if those changes are included.

\subsection{Net $\mathrm{CO}_{2}$ emission from land use change}

Total carbon on land comprises three carbon pools in vegetation $\left(c_{\mathrm{V}}\right)$, litter $\left(c_{\mathrm{L}}\right)$ and soil $\left(c_{\mathrm{S}}\right)$. Primary and secondary forests are not represented explicitly in CABLE, and are combined into one grid-cell averaged PFT fraction. This approach does not account for the difference in the amount of standing biomass carbon between the primary and secondary PFTs. Clear-cutting and wood harvest were performed at the last time step of each model year while regrowth occurred at the first step of the next year. Note that wood harvest in this study only accounted for fractional area change and associated change in carbon pool size in woody PFTs but excluding the change in standing biomass carbon from forest management without land cover change. The harvested wood was added to wood product carbon pool $c_{\mathrm{p}}^{*}$ while leaf and root biomass of those deforested PFTs was deposited in litter pools.

For land points that never experience LULCC over the simulation period $[0, t]$, the budget equations of carbon in each of these three pools are

$$
\begin{aligned}
\frac{\mathrm{d} c_{\mathrm{V}}}{\mathrm{d} t} & =f_{\mathrm{GPP}}-r_{\mathrm{V}}-f_{\mathrm{L}} \\
\frac{\mathrm{d} c_{\mathrm{L}}}{\mathrm{d} t} & =f_{\mathrm{L}}-r_{\mathrm{L}}-f_{\mathrm{S}} \\
\frac{\mathrm{d} c_{\mathrm{S}}}{\mathrm{d} t} & =f_{\mathrm{S}}-r_{\mathrm{S}},
\end{aligned}
$$

where $f_{\mathrm{GPP}}$ is gross primary production in $\mathrm{g} \mathrm{C} \mathrm{m}^{-2} \mathrm{yr}^{-1}, r_{\mathrm{V}}$, $r_{\mathrm{L}}$, and $r_{\mathrm{S}}$ are the respired $\mathrm{CO}_{2}$ from vegetation, litter and soil carbon pools in $\mathrm{g} \mathrm{Cm}^{-2} \mathrm{yr}^{-1}$, respectively; $f_{\mathrm{L}}$ and $f_{\mathrm{S}}$ 


\section{a) Total Forest Area}
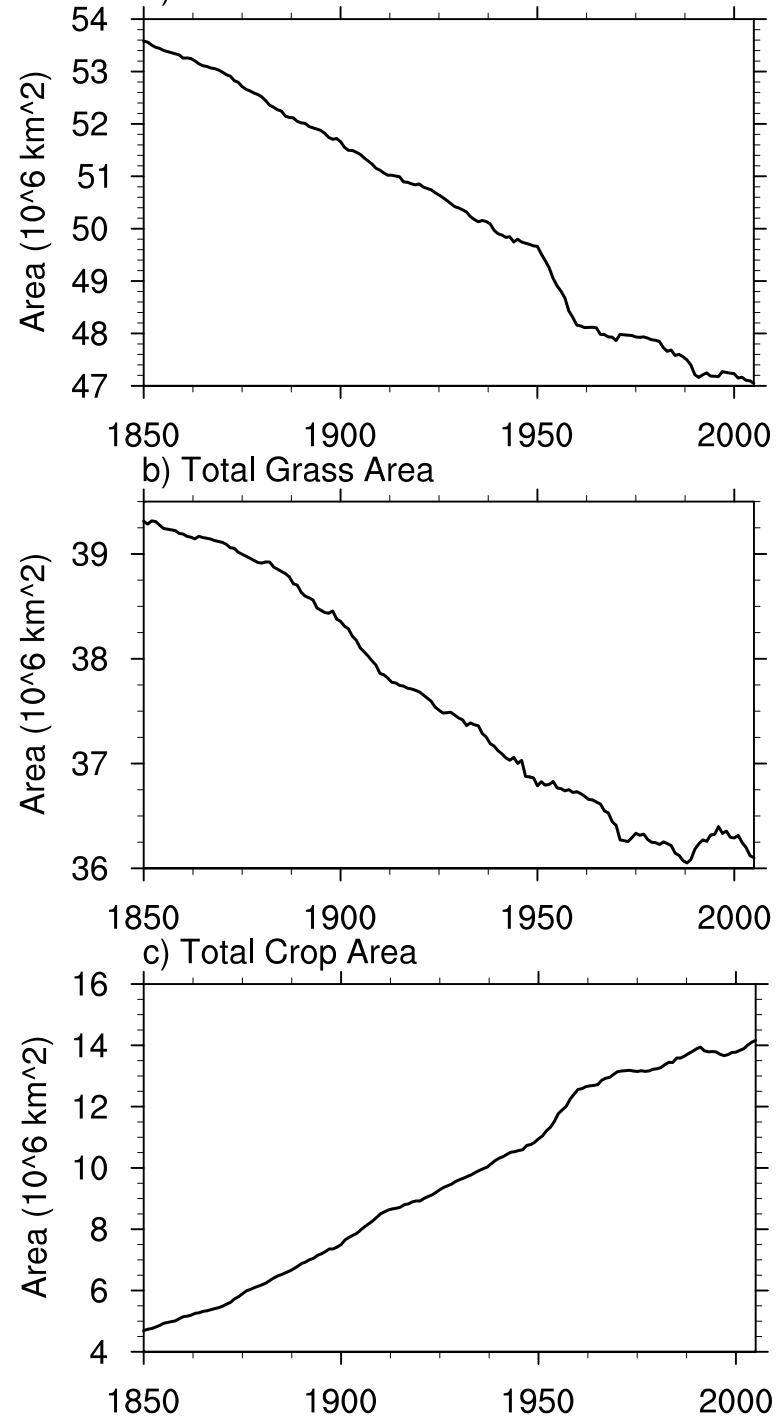

Fig. 2. CMIP-5 global historical land cover changes in land area $\left(10^{6} \mathrm{~km}^{2}\right)$. Note that the $y$ axis scale used for each land use category varies.

are carbon fluxes from vegetation to litter, and from the litter to the soil pool in $\mathrm{g} \mathrm{C} \mathrm{m}^{-2} \mathrm{yr}^{-1}$, respectively.

Land use change can affect total carbon pool sizes directly and indirectly. Land use change can affect climate through the biogeophysical effects and biogeochemical effects, and the changed climate will then impact all the fluxes on the right-hand sizes of Eqs. (1) and (3). Since atmospheric $\mathrm{CO}_{2}$ concentration from 1850 to 2005 is prescribed as an input to our model in this study, only the biogeochemical effect is taken into account here. The dynamic equations for carbon in vegetation, litter and soil of a land point under land use change over the study period are given by

$$
\begin{aligned}
\frac{\mathrm{d} c_{\mathrm{V}}^{*}}{\mathrm{~d} t} & =f_{\mathrm{GPP}}^{*}-r_{\mathrm{V}}^{*}-f_{\mathrm{L}}^{*}-f_{\mathrm{W}}^{*} \\
\frac{\mathrm{d} c_{L}^{*}}{\mathrm{~d} t} & =f_{\mathrm{L}}^{*}-r_{\mathrm{L}}^{*}-f_{\mathrm{S}}^{*} \\
\frac{\mathrm{d} c_{S}^{*}}{\mathrm{~d} t} & =f_{\mathrm{S}}^{*}-r_{\mathrm{S}}^{*} .
\end{aligned}
$$

The flux terms with star as superscript in Eqs. (4) to (6) are the equivalent fluxes in Eqs. (1) to (3) but for pools under the influences (both direct and indirect effects) of land use change, and are calculated using an earth system model that takes account of the both indirect and direct effects of land use change on all the fluxes in Eqs. (3) to (4). Even for the undisturbed land points, the fluxes are different because of the indirect effects.

The dynamics of the harvest wood carbon pool, $c_{\mathrm{P}}^{*}$, is governed by

$\frac{\mathrm{d} c_{\mathrm{P}}^{*}}{\mathrm{~d} t}=f_{\mathrm{W}}^{*}-f_{\mathrm{P}}^{*}$,

where $f_{\mathrm{w}}^{*}$ is the rate of wood harvest in $\mathrm{g} \mathrm{C} \mathrm{m}^{-2} \mathrm{yr}^{-1}$ and $f_{\mathrm{p}}^{*}$ is the associated $\mathrm{CO}_{2}$ flux released from consumption of anthropogenic pools. Similar to Shevliakova et al. (2009) we partitioned equally into three anthropogenic pools characterized by their turnover rates: fuel wood $\left(1 \mathrm{yr}^{-1}\right)$, paper and paper products $\left(0.1 \mathrm{yr}^{-1}\right)$ and wood products $\left(0.01 \mathrm{yr}^{-1}\right)$.

The net $\mathrm{CO}_{2}$ emission from land use change, $F_{\mathrm{LUC}}$, is calculated as the difference of net land carbon uptake between LUC and CTL experiments, which includes both the carbon releases from deforestation and carbon absorptions from forest regrowth:

$$
\begin{aligned}
F_{\mathrm{LUC}} & =\left(c_{\mathrm{v}}^{*}+c_{\mathrm{L}}^{*}+c_{\mathrm{S}}^{*}+c_{\mathrm{P}}^{*}\right)-\left(c_{\mathrm{V}}+c_{\mathrm{L}}+c_{\mathrm{S}}\right) \\
& =\Delta F_{\mathrm{GPP}}-\left(\Delta R_{\mathrm{V}}+\Delta R_{\mathrm{H}}\right)-F_{\mathrm{P}}
\end{aligned}
$$

where

$$
\begin{aligned}
& \Delta F_{\mathrm{GPP}}=\int_{0}^{t}\left(f_{\mathrm{GPP}}^{*}-f_{\mathrm{GPP}}\right) \mathrm{d} t \\
& \Delta R_{\mathrm{V}}=\int_{0}^{t}\left(r_{\mathrm{V}}^{*}-r_{\mathrm{V}}\right) \mathrm{d} t \\
& \Delta R_{\mathrm{H}}=\int_{0}^{t}\left(r_{\mathrm{L}}^{*}+r_{\mathrm{S}}^{*}-r_{\mathrm{L}}-r_{\mathrm{S}}\right) \mathrm{d} t \\
& F_{\mathrm{p}}=\int_{0}^{t} f_{\mathrm{P}}^{*} \mathrm{~d} t .
\end{aligned}
$$

Net ecosystem exchange (NEE) of a land point is calculated as

$$
\begin{aligned}
& f_{\mathrm{NEE}}=f_{\mathrm{GPP}}-r_{\mathrm{V}}-r_{\mathrm{L}}-r_{\mathrm{S}} \\
& f_{\mathrm{NEE}}^{*}=f_{\mathrm{GPP}}^{*}-r_{\mathrm{V}}^{*}-r_{\mathrm{L}}^{*}-r_{\mathrm{S}}^{*}-f_{\mathrm{P}}^{*} .
\end{aligned}
$$




\subsection{Effects of nutrient limitation on carbon fluxes}

Carbon fluxes in Eqs. (13) and (14) are tightly linked to $\mathrm{N}$ and $\mathrm{P}$ concentrations in plant, litter and soil pools (Wang et al., 2010). To avoid repetition, here we only give the equations for the carbon fluxes without land uses. In CABLE, $f_{\mathrm{GPP}}$ is calculated as

$f_{\mathrm{GPP}}=f_{1}\left(L, v_{\mathrm{cmax}}, j_{\max }\right)$,

where $L$ is canopy leaf area index $\left(\mathrm{m}^{2} \mathrm{~m}^{-2}\right), v_{\text {cmax }}$ and $j_{\max }$ are the maximal carboxylation rate $\left(\mathrm{mmol} \mathrm{m}^{-2} \mathrm{~s}^{-1}\right)$ and maximal rate of potential electron transport $\left(\mathrm{mmol} \mathrm{m}^{-2} \mathrm{~s}^{-1}\right)$ in the leaf photosynthesis model. $v_{\text {cmax }}$ is calculated as

$v_{\mathrm{cmax}}=a+b \cdot f\left(p_{n}\right) \cdot n_{\text {leaf }}$,

where $a$ and $b$ are two empirical coefficients according to different PFTs (see Wang et al., 2012, Table S2 for further details), $n_{\text {leaf }}$ is leaf nitrogen amount $\left(\mathrm{g} \mathrm{N} \mathrm{m}^{-2}\right), p_{n}$ is leaf phosphorus to nitrogen ratio $(\mathrm{gP} / \mathrm{g} \mathrm{N})$.

Based on the result of Reich et al. (2009), $f\left(p_{n}\right)$ for evergreen broadleaf forest is calculated as

$f\left(p_{n}\right)=0.4+9 p_{n}$.

This is also supported by the result of Kattage et al. (2009) who found the tropical trees grown at more phosphoruslimited soil (oxisols) had a lower sensitivity to leaf nitrogen than those at less phosphorus-limited soil (non-oxisols). For other PFTs, we assume that $f\left(p_{n}\right)=1$ because of lack of data.

Autotrophic plant respiration is the sum of maintenance and growth respiration. It is

$r_{\mathrm{V}}=r_{\text {leaf }}+r_{\text {wood }}+r_{\text {root }}+r_{\mathrm{G}}$,

where $r_{\text {leaf }}, r_{\text {wood }}$ and $r_{\text {root }}$ are maintenance respiration rates of leaf, wood and root in $\mathrm{g} \mathrm{C} \mathrm{m}^{-2} \mathrm{day}^{-1}, r_{\mathrm{G}}$ is growth respiration in $\mathrm{g} \mathrm{C} \mathrm{m}^{-2} \mathrm{day}^{-1}$. They are calculated as

$r_{\text {leaf }}=f_{2}\left(v_{\mathrm{cmax}}, L\right)$

$r_{\text {wood }}=r_{\mathrm{w}} N_{\mathrm{w}} \exp \left(308.56\left(\frac{1}{56.02}-\frac{1}{T_{\mathrm{a}}+46.02}\right)\right)$

$r_{\text {root }}=r_{\mathrm{r}} N_{\mathrm{r}} \exp \left(308.56\left(\frac{1}{56.02}-\frac{1}{\bar{T}_{\mathrm{s}}+46.02}\right)\right)$,

where $r_{\mathrm{w}}$ is wood maintenance respiration at daily mean air temperature $\left(T_{\mathrm{a}}\right)$ of $10^{\circ} \mathrm{C}$ in $\mathrm{gC}(\mathrm{g} \mathrm{N})^{-1} \mathrm{day}^{-1}, r_{\mathrm{r}}$ is maintenance respiration of root at a daily mean soil temperature of the rooting zone $\left(\bar{T}_{\mathrm{s}}\right)$ at $10^{\circ} \mathrm{C}$ in $\mathrm{g} \mathrm{C}(\mathrm{g} \mathrm{N})^{-1}$ day $^{-1}$. Their values are based on the estimates by Reich et al. (2008). $N_{\mathrm{w}}$ and $N_{\mathrm{r}}$ are nitrogen amount in wood and root tissue in $\mathrm{g} \mathrm{N} \mathrm{m}^{-2}$, respectively. The temperature dependence of Eqs. (20) and (21) are based on Lloyd and Taylor (1994).
Plant growth respiration is modeled as

$r_{\mathrm{G}}=\left(1-y_{g}\right) \cdot\left(f_{\mathrm{GPP}}-r_{\text {leaf }}-r_{\mathrm{wood}}-r_{\text {root }}\right)$

and

$y_{g}=0.65+0.2 \frac{p_{n}}{p_{n}+1 / 15}$.

Equation (23) is based on the work by Kerkhoff et al. (2005) who showed that plant growth respiration increases with $p_{n}$.

Respiration rates of litter $\left(r_{\mathrm{L}}\right)$ and soil $\left(r_{\mathrm{S}}\right)$ also depend on N, P states in litter and soil (Wang et al., 2010).

When plants and soils are disturbed by LULCC, the values of carbon and nutrient pool sizes will be different. According to Sects. 2.3 and 2.4, the carbon fluxes depending on pool sizes and nutrient concentrations in pools can be affected by LULCC directly. Therefore the impacts of $\mathrm{N}$ and $\mathrm{P}$ on LULCC fluxes are calculated by the differences between the two sets of experiments (LUC-CNP - CTL-CNP) - (LUCC-CTL-C).

\section{Results}

\subsection{Impacts of nutrient limitation on terrestrial carbon}

At the global scale, simulations using the $\mathrm{C}$-only mode and omitting LULCC show a strong terrestrial sink of $\mathrm{CO}_{2}$. The magnitude of this sink exceeds $200 \mathrm{Pg} \mathrm{C}$ between 1850 and 2005 (Fig. 3). Adding $\mathrm{N}$ and $\mathrm{P}$ limitation reduces this sink to $85 \mathrm{Pg} \mathrm{C}$, a result consistent with other studies that demonstrate $\mathrm{N}$ limitation strongly reduces terrestrial carbon sinks (Thornton et al., 2007; Sokolov et al., 2008; Zaehle et al., 2010). Adding LULCC has a major impact on terrestrial carbon stores. Simulations using the $\mathrm{C}$-only mode, but including LULCC, also simulate a net carbon sink ( $80 \mathrm{Pg} \mathrm{C}$ between 1850 and 2005). The sink is negligible from 1850 through to about 1960, and increases rapidly under accelerating atmospheric $\mathrm{CO}_{2}$ concentrations through to 2005. The $\mathrm{N}$ and $\mathrm{P}$ limitation reduces the capacity of the terrestrial biosphere to take up $\mathrm{CO}_{2}$ such that in the LUC-CNP simulations the land is a weak source of $\mathrm{CO}_{2}$ because emissions from land cover change are not fully offset by land carbon uptake in response to increased atmospheric $\mathrm{CO}_{2}$ (Fig. 3). Further, the acceleration in the terrestrial sink shown in the C-only LULCC simulation is largely suppressed in the CNP simulation with LULCC. Over the period 1850 and 2005, the LUC-CNP simulation therefore remains a source for $\mathrm{CO}_{2}$ with a magnitude of $12 \mathrm{Pg} \mathrm{C}$. That is, $\mathrm{N}$ and $\mathrm{P}$ limitation changes the terrestrial surface from a sink of $\mathrm{CO}_{2}$ to a net source over the period 1850 to 2005 .

The $\mathrm{CO}_{2}$ emissions from LULCC can be estimated as the difference in pool size changes from 1850 to 2005 between the simulations with and without LULCC. With Conly, the plant biomass carbon was reduced by 104.6 Pg C, litter and soil carbon by $45.5 \mathrm{Pg} \mathrm{C}$ but wood product pool 


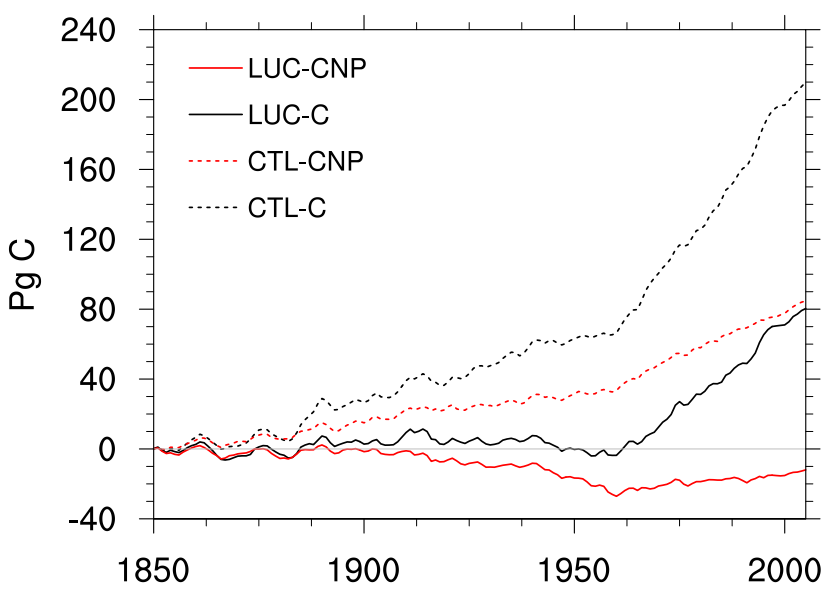

Fig. 3. Changes in total land carbon (Pg C) for 1850-2005, with and without land use change under $\mathrm{C}$-only and $\mathrm{N}$ and $\mathrm{P}$ limitation. Positive value indicates land carbon uptake from atmosphere to land.

was increased by $20.7 \mathrm{PgC}$ between the simulations with and without LULCC. The total $\mathrm{CO}_{2}$ emission from LULCC was therefore $129.6 \mathrm{Pg} \mathrm{C}$ (Fig. 4). Most of the $\mathrm{CO}_{2}$ emitted from LULCC was from the increased heterotrophic respiration $\left(0.56 \mathrm{Pg} \mathrm{C} \mathrm{yr}^{-1}\right)$ and consumption from wood products $\left(0.48 \mathrm{Pg} \mathrm{C} \mathrm{yr}^{-1}\right)$ offset slightly by an increase in gross pri-

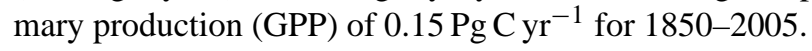

For the CNP simulation, LULCC resulted in a decrease in the plant, litter and soil carbon pools, and a small increase in wood product carbon pool (Fig. 5). As a result, the total land carbon pool, including wood product carbon, decreased by $12 \mathrm{Pg} \mathrm{C}$ from 1850 to 2005. In simulations without LULCC, plant biomass, litter and soil carbon pools increased from 1850 to 2005 . Therefore the total $\mathrm{CO}_{2}$ emission from LULCC was estimated to be 96.7 Pg from 1850 to 2005 . Compared to both simulations with and without LULCC, land use change increased GPP very negligibly, while it decreased autotrophic respiration by $0.31 \mathrm{Pg} \mathrm{C} \mathrm{yr}^{-1}$ from 1850 to 2005 , and therefore increased NPP by $0.35 \mathrm{Pg} \mathrm{C} \mathrm{yr}^{-1}$. Similar to the C-only simulations, the LULCC induced $\mathrm{CO}_{2}$ emissions, mainly due to an increase in heterotrophic respiration, by $0.55 \mathrm{Pg} \mathrm{C} \mathrm{yr}^{-1}$ and the consumption of wood products by $0.43 \mathrm{Pg} \mathrm{C} \mathrm{yr}^{-1}$ from 1850 to 2005 .

Imposing the $\mathrm{N}$ and $\mathrm{P}$ limitation in our model reduced the estimated $\mathrm{CO}_{2}$ emission from LULCC by $32.9 \mathrm{PgC}$ from 1850 to 2005. Most of this difference can be accounted by the effect of nutrient limitation on the contribution of vegetation biomass change. LULCC increased plant biomass slightly by increased NPP for both C-only and CNP simulations, and this increase was reduced by $\mathrm{N}$ and $\mathrm{P}$ limitation. On the other hand LULCC also increased the amount of carbon transferred to litter, soil and wood product pools, and thereby reduced the plant biomass carbon. The reduction in plant carbon under $\mathrm{N}$ and $\mathrm{P}$ limitation was $25 \mathrm{Pg} \mathrm{C}$ less than under C-only simulation. $\mathrm{N}$ and $\mathrm{P}$ limitation also reduced

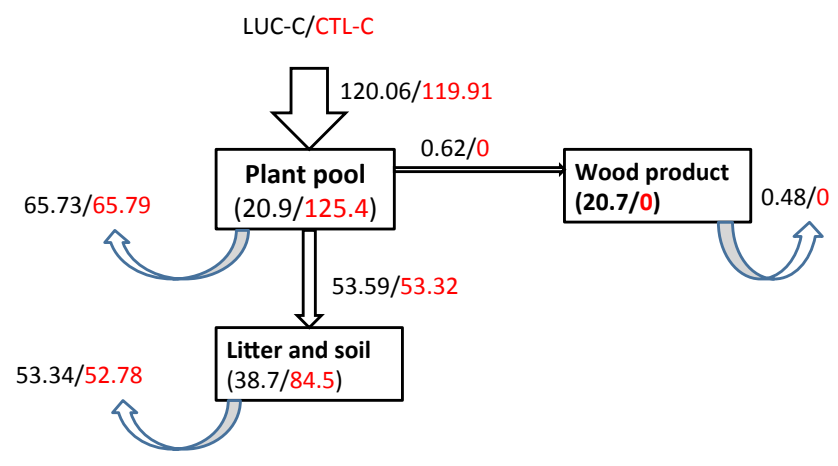

Fig. 4. Mean annual flux into different pools (the numbers beside the arrows, $\mathrm{Pg} \mathrm{C} \mathrm{yr}{ }^{-1}$ ) and change in pool sizes $(\mathrm{PgC})$ from 1850 to 2005 for C-only simulation with LULCC (black numbers) or without LULCC (red numbers).

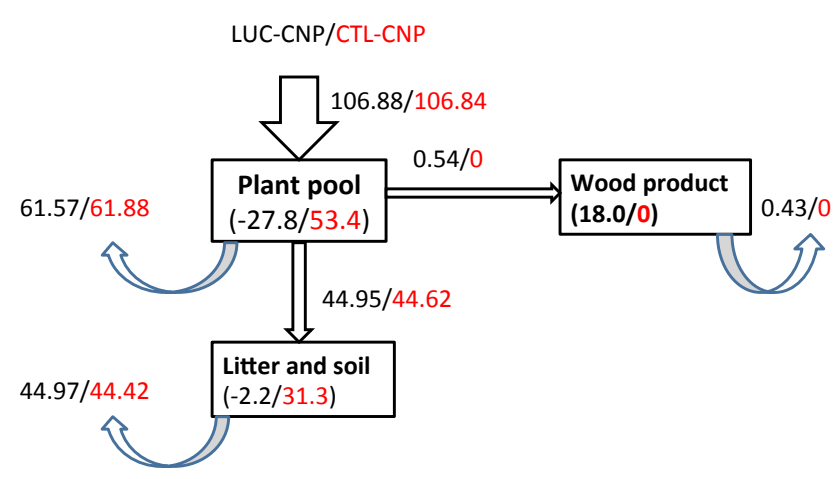

Fig. 5. Mean annual flux into different pools (the numbers beside the arrows, $\mathrm{Pg} \mathrm{C} \mathrm{yr}{ }^{-1}$ ) and change in pool sizes $(\mathrm{Pg} \mathrm{C})$ from 1850 to 2005 for CNP simulation with LULCC (black numbers) or without LULCC (red numbers).

the $\mathrm{CO}_{2}$ emission from litter, soil and wood product pools due to LULCC because all simulated pool sizes and fluxes under $\mathrm{N}$ and $\mathrm{P}$ limitation were much smaller than those under C-only simulations. However, the magnitude of changes in these pools was much less than the change in vegetation biomass pool.

The geographical pattern of changes in NEE with and without LULCC are shown in Fig. 6. These patterns include a climate signal associated with the increase in $\mathrm{CO}_{2}$ between 1850 and 2005, and a $\mathrm{CO}_{2}$ fertilization effect, as well as any impact from LULCC. The changes shown in Fig. 6 should therefore not be interpreted as simply a LULCC signal. The combined impact in the C-only simulations (Fig. 6a) includes decreases in NEE of $\sim 20-30 \mathrm{~g} \mathrm{C} \mathrm{m}^{-2} \mathrm{yr}^{-1}$ over Europe, parts of SE Asia, eastern North America, isolated parts of South America, and Africa coincident with LULCC. Increases in NEE occur over North America, Eurasia, parts of South America, and Africa of $\sim 10-30 \mathrm{~g} \mathrm{C} \mathrm{m}^{-2} \mathrm{yr}^{-1}$. Figure $6 \mathrm{c}$ shows the results from simulations excluding LULCC but with the same $\mathrm{CO}_{2}$ forcing and any associated fertilization effect as used in Fig. 6a. Here, in the C-only simulations, 

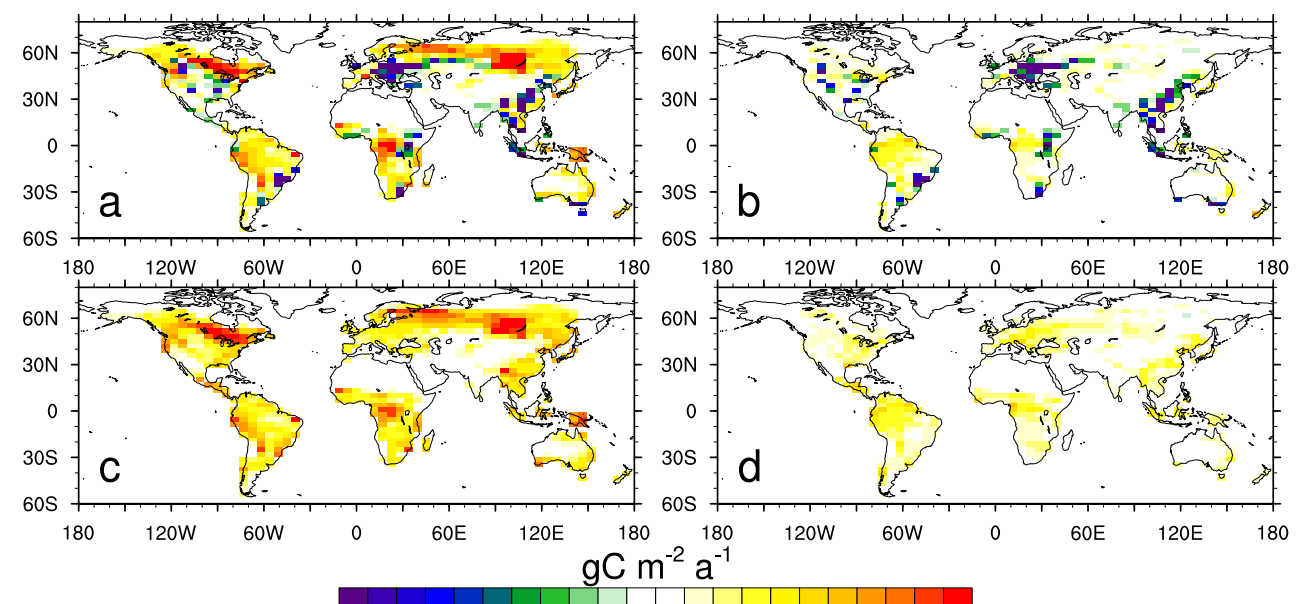

$-30-24-18-12 \quad-6 \quad 0 \quad 6 \quad 12 \quad 182430$

Fig. 6. Average annual net ecosystem exchanges (NEE) for 1850-2005 for land use change simulations under C-only (a) and CNP (b) and in the absence of LULCC but including C-only (c) and $\mathrm{N}$ and $\mathrm{P}$ limitation (d). Positive value indicates net carbon fluxes from the atmosphere to land.

NEE increases over most of the vegetated surfaces by 10 $30 \mathrm{~g} \mathrm{C} \mathrm{m}^{-2} \mathrm{yr}^{-1}$ (Fig. 6c).

In both LUC (Fig. 6b) and CTL (Fig. 6d) simulations, the addition of $\mathrm{N}$ and $\mathrm{P}$ limitation moderates the impact of climate and elevated $\mathrm{CO}_{2}$ on NEE. In the LUC experiments including $\mathrm{N}$ and $\mathrm{P}$ limitation (Fig. 6b), the areas of increased NEE largely disappear and the areas of decreased NEE become more clearly associated with LULCC particularly over Europe and SE Asia. There are still areas of increased NEE over South America and central Africa, but the magnitude has decreased from $\sim 20-30 \mathrm{~g} \mathrm{C} \mathrm{m}^{-2} \mathrm{yr}^{-1}$ (Fig. 6a) to $\sim 10 \mathrm{~g} \mathrm{C} \mathrm{m}^{-2} \mathrm{yr}^{-1}$ (Fig. 6c). Similarly, in the CTL simulations, the magnitude of the increase in NEE decreases from $10-30 \mathrm{~g} \mathrm{C} \mathrm{m}^{-2} \mathrm{yr}^{-1}$ to $\sim 10 \mathrm{~g} \mathrm{C} \mathrm{m}^{-2} \mathrm{yr}^{-1}$ when $\mathrm{N}$ and $\mathrm{P}$ limitation is included (Fig. 6d). It is interesting to compare Fig. $6 \mathrm{~b}$ and d. In the CTL (but nutrient-limited) simulations, NEE increase over Europe, eastern North America, and SE Asia by $\sim 10 \mathrm{~g} \mathrm{C} \mathrm{m}^{-2} \mathrm{yr}^{-1}$. These same regions show large reductions in NEE once LULCC is included (Fig. 6c). That is, omitting LULCC leads to a misleading conclusion on the sign of the change in NEE over the period 1850-2005. The decreases of global carbon uptakes by including $\mathrm{N}$ and $\mathrm{P}$ limitation mainly occur at the tropics and Northern Hemisphere high latitudes.

The difference between the LUC and CTL simulations can be seen in Fig. 7 where the averaged annual emissions of $\mathrm{CO}_{2}$ from LULCC for the period 1850-2005 are shown. The impact of LULCC can be clearly seen in both C-only and the CNP simulations. However, there is a general reduction in the area affected when $\mathrm{N}$ and $\mathrm{P}$ limitation is included and the larger changes become more geographically constrained to areas of intensive LULCC. This is most clear in Fig. 7c, which shows the difference between the land use emissions in the C-only simulation (Fig. 7a) and those from the CNP simulations (Fig. 7b). First, the pattern of LULCC can be clearly seen in Fig. 7c as we would expect if the impact of LULCC on emissions is substantially constrained to the regions of LULCC and remote changes are limited. Also noteworthy is that Fig. 7c highlights a general tendency to positive values, pointing to higher LULCC emissions in the $\mathrm{C}$-only simulation. Thus, the addition of nutrient limitation tends to offset the impact of LULCC on carbon loss over the historical period.

\subsection{Impact of nutrient limitation on climate}

Warming between 1850 and 2005 due to the increase in atmospheric $\mathrm{CO}_{2}$ is shown in Fig. 8. Simulations with and without LULCC, and with and without $\mathrm{N}$ and $\mathrm{P}$ limitation show very similar overall changes in temperature, which is to be expected given all models are forced using the same $\mathrm{CO}_{2}$ and aerosols, and SSTs. Clearly, LULCC and N and P limitation are small effects on climate at the global scale in comparison to human emissions of $\mathrm{CO}_{2}$. That said, LULCC does lead in our simulations to a small reduction in the amount of $\mathrm{CO}_{2}$-induced warming. In the $\mathrm{C}$-only simulations, warming is reduced from $0.87^{\circ} \mathrm{C}$ to $0.76^{\circ} \mathrm{C}$. This is consistent with earlier experiments, suggesting LULCC cools the planet on the global average. In the NP-limited simulations, the warming of $0.78^{\circ} \mathrm{C}$ is reduced to $0.72^{\circ} \mathrm{C}$. Overall, this suggests that LULCC offsets global warming (although by a very small amount on the global average) but the inclusion of $\mathrm{N}$ and $\mathrm{P}$ limitation reduces the impact of LULCC. While LULCC reduces warming by $0.11^{\circ} \mathrm{C}$, with $\mathrm{N}$ and $\mathrm{P}$ limitation included, this is reduced to $0.06^{\circ} \mathrm{C}$ (Table 1). This is clear in the regional impacts of LULCC on temperature that is strongly regionalized (Pitman et al., 2009). In our simulations, LULCC cools primarily over North America and 


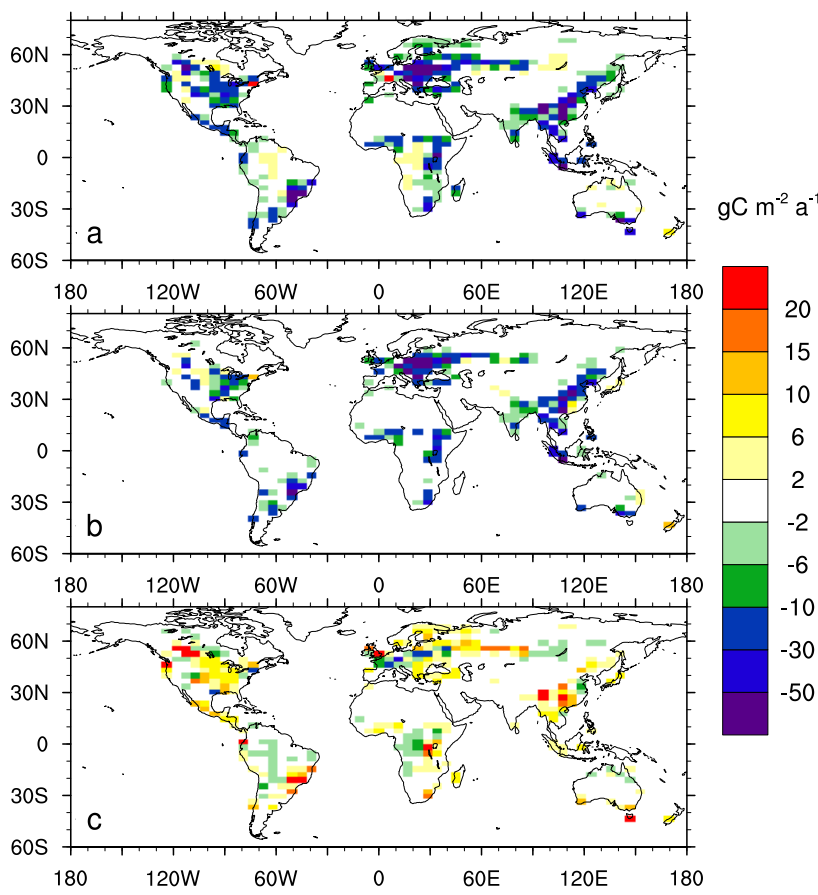

Fig. 7. Average annual land use carbon emissions from 1850 to 2005 for C-only mode (a), CNP mode (b), and difference between the Conly and CNP simulations (c). Positive values indicate net carbon fluxes from the atmosphere to the land.

Eurasia by $\sim 0.5^{\circ} \mathrm{C}$ for the C-only simulation (Fig. 9a). Impacts are not statistically significant at a $90 \%$ confidence level elsewhere. Adding $\mathrm{N}$ and $\mathrm{P}$ limitation affects the spatial extent of significant cooling over both North America and Eurasia (Fig. 9b) but not its magnitude. Further study with much larger ensemble of simulations is required to ascertain this with confidence.

The biogeophysical impacts of LULCC are also shown in Table 1 for different regions. Including LULCC reduced warming, as a result of the increase in surface albedo by 0.003 to 0.005 , and decreases in net surface radiation absorptions by $\sim 1 \mathrm{~W} \mathrm{~m}^{-2}$ and sensible heat flux by about $1 \mathrm{~W} \mathrm{~m}^{-2}$. This cooling impact of LULCC is stronger in Northern Hemisphere mid- and high latitudes for both the C-only and CNP cases. Compared to the C-only case, inclusion of $\mathrm{N}$ and $\mathrm{P}$ limitation reduced the effect of LULCC on surface climate globally except in Northern Hemisphere midlatitudes from 1850 to 2005 . This is clearly shown in Fig. 9: the spatial expansion of LULCC-induced changes in surface albedo and net surface radiation absorptions become statistically insignificant if nutrient limitation is accounted for.

\section{Global Land Surface Air Temperature $\left({ }^{\circ} \mathrm{C}\right)$}

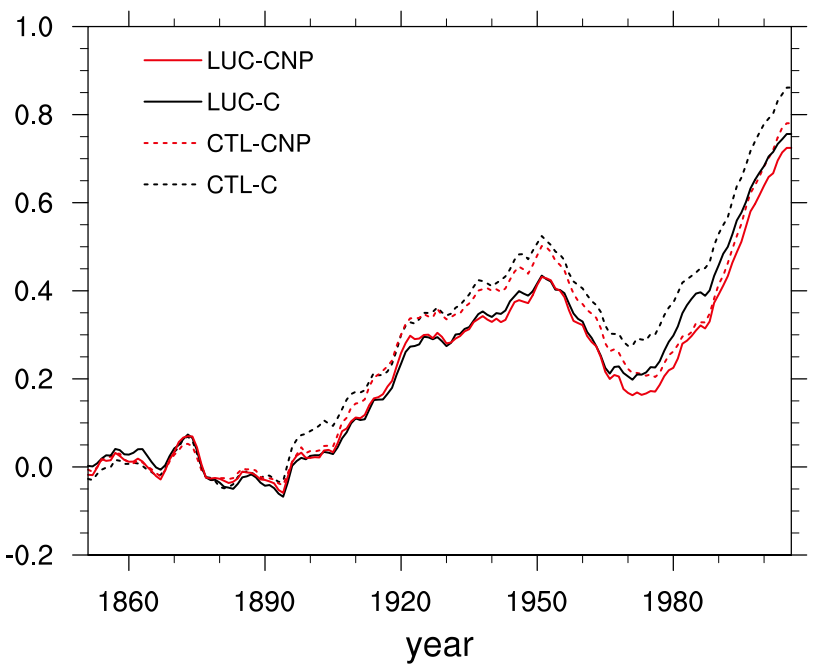

Fig. 8. Average increases of annual surface temperature for 1850 2005 for each simulation ( $20 \mathrm{yr}$ running average, ${ }^{\circ} \mathrm{C}$ ).

\section{Discussion and conclusions}

In a range of earlier studies, LULCC has been shown to be an important driver of regional temperature change, at least over those regions where changes have been significant (Pielke et al., 2011 and references therein). Most of these studies have focused on the biogeophysical impacts of LULCC and have shown, most commonly, cooling in the higher latitudes (Lawrence and Chase, 2010). This is associated with the dominance of the albedo impacts of LULCC and the associated snow-albedo feedback in high latitudes, which tends to cool on the annual average. In this study, our results suggest LULCC cools on the global average by about $0.1^{\circ} \mathrm{C}$ without nutrient limitation (Fig. 8). This cooling grows through the period 1850-1920 but from around 1940 remains similar. If nutrients are included, LULCC still cools the global mean temperature, but only by around $0.05^{\circ} \mathrm{C}$ with a similar temporal pattern shown for the non-limited simulations. In all our simulations, the statistically significant impact of LULCC on climate remains limited to regions of intensive change (Fig. 9). Our results therefore provide support for including LULCC when examining regional-scale impacts, particularly in regions of intense LULCC (de NobletDucoudré et al., 2012). Our results suggest that the impact of LULCC on regional-scale temperature may be overestimated if $\mathrm{N}$ and $\mathrm{P}$ limitation are not incorporated (Table 1).

Focusing on the impact of LULCC on the terrestrial carbon balance, our results suggest LULCC has a major impact on changes of total land carbon over the period 1850 2005. In carbon-only simulations, the inclusion of LULCC decreases the additional land carbon stored in 2005 from around $210 \mathrm{PgC}$ to $80 \mathrm{PgC}$ (Fig. 3). As anticipated, based 

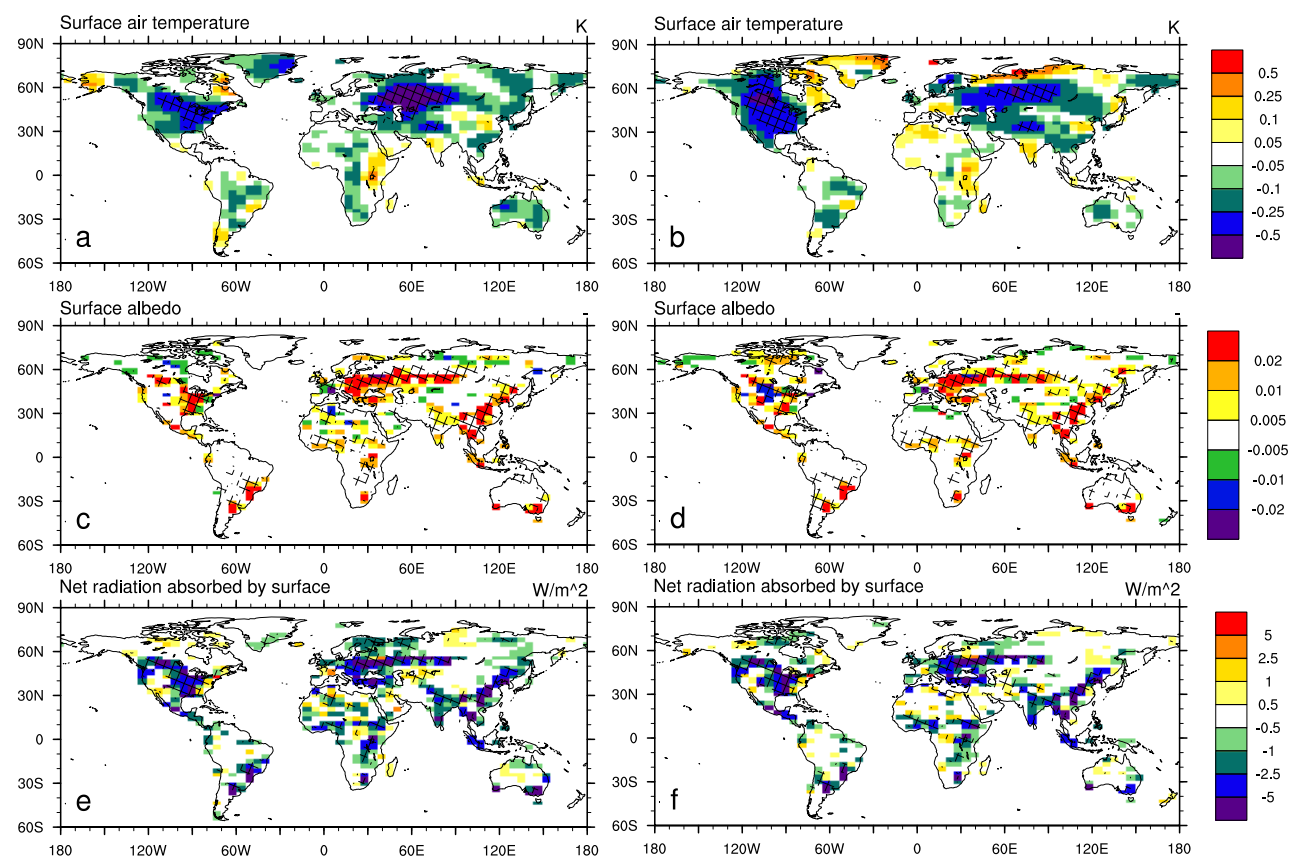

Fig. 9. Differences of annually averaged surface air temperature $\left({ }^{\circ} \mathrm{C}\right)$, surface albedo and net radiation $\left(\mathrm{W} \mathrm{m}^{-2}\right)$ absorbed by surface for 1986-2005 between LUC and CTL simulations under C-only (left column) and NP (right column) limitation. The areas exceeding $90 \% t$ test confidence level are marked.

Table 1. Biogeophysical impacts of LULCC for global, tropics $\left(20^{\circ} \mathrm{S}-20^{\circ} \mathrm{N}\right)$, southern hemisphere mid-latitudes ( $\mathrm{SH}-\mathrm{mid}, 20^{\circ} \mathrm{S}-$ $50^{\circ} \mathrm{S}$ ), Northern Hemisphere mid-latitudes (NH-mid, $20^{\circ} \mathrm{N}-$ $50^{\circ} \mathrm{N}$ ) and Northern Hemisphere high latitudes (NH-high, $50^{\circ} \mathrm{N}-$ $90^{\circ} \mathrm{N}$ ) for the period 1976-2005. Variables shown are differences between LUC and CTL simulations: Land surface air temperature (Temp, ${ }^{\circ} \mathrm{C}$ ); Land surface albedo (fraction); Net radiation absorbed by surface (Rnet, $\left.\mathrm{W} \mathrm{m}^{-2}\right)$; Land sensible heat flux $\left(\mathrm{W} \mathrm{m}^{-2}\right)$; and Land latent heat flux $\left(\mathrm{W} \mathrm{m}^{-2}\right)$.

\begin{tabular}{llrrrrr}
\hline Region & Experiment & Temp & Albedo & Rnet & Sensible & Latent \\
\hline Global & C & -0.11 & 0.0045 & -0.93 & -0.83 & -0.08 \\
& CNP & -0.06 & 0.0037 & -0.73 & -0.74 & 0.04 \\
SH-mid & C & -0.04 & 0.0050 & -1.19 & -0.98 & -0.15 \\
& CNP & -0.02 & 0.0049 & -1.11 & -0.74 & -0.35 \\
Tropics & C & -0.03 & 0.0041 & -1.05 & -1.07 & 0.07 \\
& CNP & 0.00 & 0.0028 & -0.57 & -0.68 & 0.13 \\
NH-mid & C & -0.11 & 0.0049 & -1.02 & -0.69 & -0.32 \\
& CNP & -0.14 & 0.0040 & -1.03 & -1.12 & 0.14 \\
NH-high & C & -0.20 & 0.0042 & -0.48 & -0.59 & 0.09 \\
& CNP & -0.13 & 0.0043 & -0.37 & -0.30 & -0.07 \\
\hline
\end{tabular}

on earlier simulations using our modeling system (Zhang et al., 2011) adding $\mathrm{N}$ and $\mathrm{P}$ limitation significantly decreases the scale of the terrestrial carbon sink from $210 \mathrm{PgC}$ to $85 \mathrm{Pg} \mathrm{C}$ (Fig. 3). Adding LULCC on top of this system changes the sign of the terrestrial carbon flux from a sink ( $85 \mathrm{Pg} \mathrm{C})$ to a source (12 Pg C, Fig. 3). The changes of carbon stores in vegetation, soil and wood production pools are shown in Figs. S1-S3. The change in land biosphere from a carbon source to a sink in Fig. 3 is mainly due to the combined effects of accelerating atmospheric $\mathrm{CO}_{2}$ increases (see also Fig. 1; Zhang et al., 2011) and decreasing rates for global deforestation (Fig. 2) after the 1960s. We suggest that this has important implications for examining the impact of LULCC on the historical period; simulations of LULCC in a non-nutrient-limited system will be dominated by the $\mathrm{CO}_{2}$ fertilization effect and an overly efficient uptake of $\mathrm{CO}_{2}$ by the biosphere. This masks the impacts of LULCC. Once nutrients are included, $\mathrm{CO}_{2}$ fertilization becomes less efficient and the lower uptake of $\mathrm{CO}_{2}$ by the land can be more clearly affected by LULCC, allowing for a more accurate account of the net biogeophysical and biogeochemical impacts of LULCC to be determined. The significance of this result depends on how generalizable our results are to other modelling systems and highlights the conclusion by Arneth et al. (2010) that examining how LULCC interacts with biogeochemical cycling is a research priority.

Our estimate of $\mathrm{CO}_{2}$ emissions from LULCC is $130 \mathrm{PgC}$ for C-only or $97 \mathrm{Pg}$ C for CNP simulation from 1850 to 2005. These estimates are lower than the estimate of $155 \mathrm{Pg} \mathrm{C}$ using the book-keeping method by Houghton (2008) over the same period and much higher than the estimate of $40-77 \mathrm{Pg} \mathrm{C}$ by Arora and Boer (2010) from 1850 to 2000. The $80 \mathrm{Pg} \mathrm{C}$ net sink as estimated for LUC-C approaches the higher end of the estimated land sink of 23-90 Pg C by Arora and Boer (2010), whereas the $12 \mathrm{PgC}$ land source for LUC-CNP compares well with the source of $\sim 10 \mathrm{PgC}$ inversely calculated from 
other better-constrained fluxes (Denman et al., 2007). Based on the same interpretation of land cover trajectories from Hurtt et al. (2006), the LULCC emission (119 Pg C) simulated by CLM4 with N limitation (Lawrence et al., 2012) is consistent but lower than our C-only estimate $(130 \mathrm{Pg} \mathrm{C})$ and higher than the estimate for CNP (97 Pg C). CLM4 also produced a land carbon source of $68 \mathrm{PgC}$ for the 1850-2005 period, which is higher than the estimated source of $12 \mathrm{Pg} \mathrm{C}$ in our LUC-CNP simulation.

Our study shows that nutrient limitation significantly reduced $\mathrm{CO}_{2}$ emission from LULCC from 1850 to 2005, and this has significant implications on the global carbon budget. From 1850 to 2005, the total $\mathrm{CO}_{2}$ emission from fossil fuel burning was estimated to be $314 \mathrm{Pg} \mathrm{C}$ (Andres et al., 2011), about $200 \mathrm{PgC}$ was accumulated in the atmosphere, $135 \mathrm{Pg} \mathrm{C}$ was taken up by the ocean (Khatiwala et al., 2009). If the $\mathrm{CO}_{2}$ emission from LULCC was $97 \mathrm{Pg} \mathrm{C}$ over the same period, the accumulated land carbon uptake is calculated as $76 \mathrm{Pg} \mathrm{C}$ for the nutrient-limiting simulation, which is $21 \mathrm{Pg} \mathrm{C}$ less than the estimated land carbon uptake from 1960 to 2005 by Canadell et al. (2007).

As stated by Houghton et al. (2012), the high uncertainty in estimating carbon fluxes is linked to LULCC not only because of uncertainties in rates of changes in land surface, but also because of the incomplete processes adopted by different models (e.g. wood harvest and shifting cultivation). It is also conceivable that using estimated $\mathrm{N}$ and $\mathrm{P}$ depositions for the 1990s for the whole simulation period in this study would likely underestimate the effects on nutrient limitation on land carbon uptakes. The overall effect is likely to be secondary, and will not substantially alter our conclusion. This will be explored in the future. We note that there are inevitably some other caveats to our study. It is dependent on one Earth system model, one representation of the biogeochemical cycles and one implementation of LULCC. We have also used prescribed SSTs from earlier simulations with our modeling system, which has the potential to suppress impacts from LULCC (Davin and de Noblet-Ducoudré, 2010). Clearly, we would advocate experiments such as ours being repeated with other Earth system models that include $\mathrm{N}$ and $\mathrm{P}$ limitation. That said, we suspect that our core conclusion that the inclusion of $\mathrm{N}$ and $\mathrm{P}$ limitation reduces the impact of LULCC on both temperature and on the terrestrial carbon balance will be supported by other modeling results in the future.

\section{Supplementary material related to this article is available online at: http://www.earth-syst-dynam.net/4/ 333/2013/esd-4-333-2013-supplement.pdf.}

Acknowledgements. The authors thank Leon Rotstayan and his team for providing the modeled sea surface temperature data from their simulations, and the financial support of NSFC 41305083, China Scholarship Council and China MOST No. 2010CB951802 to Qian Zhang, and the Australian department of Climate Change and Energy efficiency to Ying Ping Wang. This work was supported by the Australian Research Council Centre of Excellence for Climate System Science grant CE110001028, and via Discovery Grant DP110102618.

Edited by: R. Betts

\section{References}

Abramowitz, G., Pitman, A. J., Gupta, H., Kowalczyk, E., and Wang, Y.: Systematic bias in land surface models, J. Hydrometeorol., 8, 989-1001, doi:10.1175/JHM628.1, 2007.

Abramowitz, G., Leuning, R., Clark, M., and Pitman, A. J.: Evaluating the performance of land surface models, J. Climate, 21, 5468-5481, 2008.

Andres, R. J., Gregg, J. S., Losey, L., Marland, G., and Boden, T. A.: Monthly, global emissions of carbon dioxide from fossil fuel consumption, Tellus B, 63, 309-327, 2011.

Arneth, A., Harrison, S. P., Zaehle, S., Tsigaridis, K., Menon, S., Bartlein, P. J., Feichter, J., Korhola, A., Kulmala, M., O’Donnell, D., Schurgers, G., Sorvari, S., and Vesala T.: Terrestrial biogeochemical feedbacks in the climate system, Nat. Geosci., 3, 525532, doi:10.1038/ngeo905, 2010.

Arora, V. and Boer, G. J.: Uncertainties in the $20^{\text {th }}$ century carbon budget associated with land use change, Glob. Change Biol., 16, 3327-3348, doi:10.1111/j.1365-2486.2010.02202.x, 2010.

Avila, F. B., Pitman, A. J., Donat, M., Alexander, L., and Abramowitz G.: Climate model simulated changes in temperature extremes due to land cover change, J. Geophys. Res., 117, D04108, doi:10.1029/2011JD016382, 2012.

Bala, G., Caldeira, K., Wickett, M., Phillips, T. J., Lobell, D. B., Delire, C., and Mirin, A.: Combined climate and carbon-cycle effects of large-scale deforestation, P. Natl. Acad. Sci. USA, 106, 6550-6555, doi:10.1073/pnas.0608998104, 2007.

Boisier, J. P., de Noblet-Ducoudré, N., Pitman, A. J., Cruz, F., Delire, C., van den Hurk, B. J. J. M., van der Molen, M. K., Müller, C., and Voldoire, A.: Attributing the biogeophysical impacts of Land-Use induced Land-Cover Changes on surface climate to specific causes. Results from the first LUCID set of simulations, J. Geophys. Res., 117, D12116, doi:10.1029/2011JD017106, 2012.

Bonan, G. B.: Effects of land use on the climate of the United States, Climatic Change, 37, 449-486, 1997.

Bonan, G. B.: Forests and climate change: forcings, feedbacks, and the climate benefits from the forests, Science, 320, 1444-1449, doi:10.1126/science.1155121, 2008.

Brovkin, V., Sitch, S., von Bloh, W., Claussen, M., Bauer, E., and Cramer, W.: Role of land cover changes for atmospheric $\mathrm{CO}_{2}$ increase and climate change during the last 150 years, Glob. Change Biol., 10, 1253-1266, 2004.

Canadell, J. G., Le Quéré, C., Raupach, M. R., Field, C., Buitenhuis, E. T., Ciais, P., Conway, T. J., Gillett, N. P., Houghton, R. A., and Marland, G.: Contributions to accelerating atmospheric $\mathrm{CO}_{2}$ growth from economic activity, carbon intensity, and efficiency 
of natural sinks, P. Natl. Acad. Sci. USA, 104, 18866-18870, doi:10.1073/pnas.0702737104, 2007.

Davin, E. L. and de Noblet-Ducoudré, N.: Climatic impact of global-scale deforestation: Radiative versus nonradiative processes, J. Climate, 23, 97-112, 2010.

de Noblet-Ducoudré, N., Boisier, J. P., Pitman, A. J., Bonan, G. B., Brovkin, V., Cruz, F., Delire, C., Gayler, V., van den Hurk, B. J. J. M., Lawrence, P. J., van der Molen, M. K., Müller, C., Reick, C. H., Strengers, B. J., and Voldoire, A.: Determining robust impacts of land-use induced land-cover changes on surface climate over North America and Eurasia: Results from the first set of LUCID experiments, J. Climate, 25, 3261-3281, 2012.

Denman, K. L., Brasseur, G., Chidthaisong, A., Ciais, P., Cox, P. M., Dickinson, R. E., Hauglustaine, D., Heinze, C., Holland, E., Jacob, D., Lohmann, U., Ramachandran, S., da Silva Dias, P. L., Wofsy S. C., and Zhang, X.: Couplings Between Changes in the Climate System and Biogeochemistry, in: Climate Change 2007: The Physical Science Basis. Contribution of Working Group I to the Fourth Assessment Report of the Intergovernmental Panel on Climate Change, edited by: Solomon, S., Qin, D., Manning, M., Chen, Z., Marquis, M., Averyt, K. B., Tignor, M., and Miller, H. L., Cambridge University Press, Cambridge, United Kingdom and New York, NY, USA, 2007.

Dentener, F. J.: Global Maps of Atmospheric Nitrogen Deposition, 1860, 1993, and 2050, Data set, available at: http://daac.ornl.gov/ (last access: 2 August 2012), from Oak Ridge National Laboratory Distributed ActiveA rchive Center, Oak Ridge, Tennessee, US, 2006.

Feddema, J. J., Oleson, K. W., Bonan, G. B., Mearns, L. O., Buja, L. E., Meehl G. A., and Washington, W. M.: The importance of land-cover change in simulating future climates, Science, 310, 1674-1678, doi:10.1126/science.1118160, 2005.

Field, C., Jackson, R., and Mooney, H.: Stomatal responses to increased $\mathrm{CO}_{2}$ : implications from the plant to the global scale, Plant Cell. Environ., 18, 1214-1225, 1995.

Findell, K. L., Shevliakova, E., Milly, P. C. D., and Stouffer, R. J.: Modeled impact of anthropogenic land cover change on climate, J. Climate, 20, 3621-3634, 2007.

Findell, K. L., Pitman, A. J., England, M. H., and Pegion, P.: Regional and Global Impacts of Land Cover Change and Sea Surface Temperature Anomalies, J. Climate, 22, 3248-3269, 2009.

Friedlingstein, P., Cox, P., Betts, R., Bopp, L., von Bloh, W., Brovkin, V., Cadule, P., Doney, S., Eby, M., Fung, I., Bala, G., John, J., Jones, C., Joos, F., Kato, T., Kawamiya, M., Knorr, W., Lindsay, K., Matthews, H. D., Raddatz, T., Rayner, P., Reick, C., Roeckner, E., Schnitzler, K. G., Schnur, R., Strassmann, K., Weaver, A. J., Yoshikawa, C., and Zeng, N.: Climate-carbon cycle feedback analysis: Results from the C4MIP model intercomparison, J. Climate, 19, 3337-3353, 2006.

Gallo, K. P., Owen, T. W., Easterling, D. R., and Jamason, P. F.: Temperature trends of the U.S. historical climatology network based on satellite designated land use/land cover, J. Climate, 12, 1344-1348, 1999.

Houghton, R. A.: Carbon Flux to the Atmosphere from Land-Use Changes: 1850-2005. In TRENDS: A Compendium of Data on Global Change, Carbon Dioxide Information Analysis Center, Oak Ridge National Laboratory, U.S. Department of Energy, Oak Ridge, Tenn., USA, 2008.
Houghton, R. A. and Goodale, C. L.: Effects of land-use change on the carbon balance of terrestrial ecosystems, in: Ecosystems and Land Use Change, edited by: DeFries, R. S., Asner, G. P., and Houghton, R. A., 85-98, American Geophysical Union, Washington, DC, 2004.

Houghton, R. A., House, J. I., Pongratz, J., van der Werf, G. R., DeFries, R. S., Hansen, M. C., Le Quéré, C., and Ramankutty, N.: Carbon emissions from land use and land-cover change, Biogeosciences, 9, 5125-5142, doi:10.5194/bg-9-5125-2012, 2012.

Hurtt, G. C., Frolking, S., Fearon, M. G., Moore III, B., Shevliakova, E., Malyshev, S., Pacala, S., and Houghton, R. A.: The underpinnings of land-use history: three centuries of global gridded land-use transitions, wood harvest activity, and resulting secondary lands, Glob. Change Biol., 12, 1-22, doi:10.1111/j.13652486.2006.01150.x, 2006.

Kattge, J., Knorr, W., Raddatz, T., and Wirth, C.: Quantifying photosynthetic capacity and its relationship to leaf nitrogen content for global-scale terrestrial biosphere models, Glob. Change Biol., 15, 976-991, 2009.

Kerkhoff, A. J., Enquist, B. J., Elser, J. J., and Fagan, W. F.: Plant allometry, stoichiometry and the temperature-dependence of primary productivity, Global Ecol. Biogeogr., 14, 585-598, 2005.

Khatiwala, S., Primeau, F., and Hall, T.: Reconstruction of the history of anthropogenic $\mathrm{CO}_{2}$ concentrations in the ocean, Nature, 462, 346-349, 2009.

Lawrence, P. J. and Chase, T. N.: Investigating the climate impacts of global land cover change in the community climate system model, Int. J. Climatol., 30, 2066-2087, doi:10.1002/joc.2061, 2010.

Lawrence, P. J., Feddema, J. J., Bonan, G. B., Meehl, G. A., O'Neill, B. C., Levis, S., Lawrence, D. M., Oleson, K. W., Kluzek, E., Lindsay, K., and Thornton, P. E.: Simulating the biogeochemical and biogeophysical impacts of transient land cover change and wood harvest in the Community Climate System Model (CCSM4) from 1850 to 2100, J. Climate, CCSM4 Special Collection, 25, 3071-3095, doi:10.1175/JCLI-D-11-00256.1, 2012.

Le Quéré, C., Raupach, M. R., Canadell, J. G., Marland, G., Bopp, L., Ciais, P., Conway, T. J., Doney, S. C., Feely, R. A., Foster, P., Friedlingstein, P., Gurney, K. R., Houghton, R. A., House, J. I., Huntingford, C., Levy, P. E., Lomas, M. R., Majkut, J., Metzl, N., Ometto, J., Peters, G. P., Prentice, I. C., Randerson, J. T., Running, S. W., Sarmiento, J. L., Schuster, U., Sitch, S., Takahashi, T., Viovy, N., van der Werf, G. R., and Woodward, F. I.: Trends in the sources and sinks of carbon dioxide, Nat. Geosci., 2, 831836, doi:10.1038/NGEO689, 2009.

Levis, S.: Modeling vegetation and land use in models of the Earth System, WIREs, Climatic Change, 1, 1-17, doi:10.1002/wcc.83, 2010.

Lloyd, J. and Taylor, J. A.: On the temperature dependence of soil respiration, Funct. Ecol, 8, 315-323, 1994.

Lobell, D. B., Bonfils, C., and Faurès, J. M.: The Role of Irrigation Expansion in Past and Future Temperature Trends, Earth Interact., 12, 1-11, 2008.

Mahowald, N., Jickells, T. D., Baker, A. R., Artaxo, P., BenitezNelson, C. R., Bergametti, G., Bond, T. C., Chen, Y., Cohen, D. D., Herut, B., Kubilay, N., Losno, R., Luo, C., Maenhaut, W., McGee, K. A., Okin, G. S., Siefert, R. L., and Tsukuda, S.: Global distribution of atmospheric phosphorus sources, concentrations and deposition rates, and anthropogenic impacts, Global 
Biogeochem. Cy., 22, GB4026, doi:10.1029/2008GB003240, 2008.

Mao, J., Phipps, S. J., Pitman, A. J., Wang, Y. P., Abramowitz, G., and Pak, B.: The CSIRO Mk3L climate system model v1.0 coupled to the CABLE land surface scheme v1.4b: evaluation of the control climatology, Geosci. Model Dev., 4, 1115-1131, doi:10.5194/gmd-4-1115-2011, 2011.

Meinshausen, M., Smith, S. J., Calvin, K., Daniel, J. S., Kainuma, M. L. T., Lamarque, J. F., Matsumoto, K., Montzka, S. A., Raper, S. C. B., Riahi, K., Thomson, A., Velders, G. J. M., and van Vuuren, D. P. P.: The RCP greenhouse gas concentrations and their extensions from 1765 to 2300, Climatic Change, 109, 213-241, 2011.

Niyogi, D., Kishtawal, C. M., Tripathi, S., and Govindaraju, R. S.: Observational evidence that agricultural intensification and land use change may be reducing the Indian Summer Monsoon rainfall, Water Resour. Res., 46, W03533, doi:10.1029/2008WR007082, 2010.

Phipps, S. J., Rotstayn, L. D., Gordon, H. B., Roberts, J. L., Hirst, A. C., and Budd, W. F.: The CSIRO Mk3L climate system model version 1.0 - Part 1: Description and evaluation, Geosci. Model Dev., 4, 483-509, doi:10.5194/gmd-4-483-2011, 2011.

Pielke, R. A. Sr., Pitman, A. J., Niyogi, D., Mahmood, R., McAlpine, C., Hossain, F., Klein Goldewijk, K., Nair, U., Betts, R., Fall, S., Reichstein, M., Kabat, P., and de Noblet-Ducoudré, N.: Land use/land cover changes and climate: Modeling analysis and observational evidence, WIREs Climatic Change, 2, 828850, doi:10.1002/wcc.144, 2011.

Pitman, A. J., de Noblet-Ducoudré, N., Cruz, F. T., Davin, E. L., Bonan, G. B., Brovkin, V., Claussen, M., Delire, C., Ganzeveld, L., Gayler, V., van den Hurk, B. J. J. M., Lawrence, P. J., van der Molen, M. K., Muller, C., Reick, C. H., Seneviratne, S. I., Strengers, B. J., and Voldoire, A.: Uncertainties in climate responses to past land cover change: First results from the LUCID intercomparison study, Geophys. Res. Lett., 36, L14814, doi:10.1029/2009GL039076, 2009.

Pitman, A. J., de Noblet-Ducoudré, N., Avila, F. B., Alexander, L. V., Boisier, J.-P., Brovkin, V., Delire, C., Cruz, F., Donat, M. G., Gayler, V., van den Hurk, B., Reick, C., and Voldoire, A.: Effects of land cover change on temperature and rainfall extremes in multi-model ensemble simulations, Earth Syst. Dynam., 3, 213 231, doi:10.5194/esd-3-213-2012, 2012.

Pongratz, J., Reick, C. H., Raddatz, T., and Claussen, M.: Effects of anthropogenic land cover change on the carbon cycle of the last millennium, Global Biogeochem. Cy., 23, GB4001, doi:10.1029/2009GB003488, 2009.

Pongratz, J., Reick, C. H., Raddatz, T., and Claussen, M.: Biogeophysical versus biogeochemical climate response to historical anthropogenic land cover change, Geophys. Res. Lett., 37, L08702, doi:10.1029/2010GL043010, 2010.

Pongratz, J., Reick, C. H., Raddatz, T., Caldeira, K., and Claussen, M.: Past land use decisions have increased mitigation potential of reforestation, Geophys. Res. Lett., 38, L15701, doi:10.1029/2011GL047848, 2011.

Reich, P. B., Tjoelker, M. G., Pregitzer, K. S., Wright, I. J., Oleksyn, J., and Machado, J. L.: Scaling of respiration to nitrogen in leaves, stems and roots of higher land plants, Ecol. Lett., 11, 793801,2008
Reich, P. B., Oleksyn, J., and Wright, I. J.: Leaf phosphorus infuences the photosynthesis- nitrogen relation: a cross-biome analysis of 314 species, Oecologia, 160, 207-212, 2009.

Rotstayn, L. D., Collier, M. A., Feng, Y., Gordon, H. B., O’Farrell, S. P., Smith, I. N., and Syktus, J.: Improved simulation of Australian climate and ENSO-related rainfall variability in a GCM with an interactive aerosol treatment, Int. J. Climatol., 30, 10671088, doi:10.1002/joc.1952, 2010.

Rotstayn, L. D., Jeffrey, S. J., Collier, M. A., Dravitzki, S. M., Hirst, A. C., Syktus, J. I., and Wong, K. K.: Aerosol- and greenhouse gas-induced changes in summer rainfall and circulation in the Australasian region: a study using single-forcing climate simulations, Atmos. Chem. Phys., 12, 6377-6404, doi:10.5194/acp-126377-2012, 2012.

Shevliakova, E., Pacala, S. W., Malyshev, S., Hurtt, G. C., Milly, P. C. D., Caspersen, J. P., Sentman, L. T., Fisk, J. P., Wirth, C., and Crevoisier, C.: Carbon cycling under 300 years of land use change: Importance of the secondary vegetation sink, Global Biogeochem. Cy., 23, GB2022, doi:10.1029/2007GB003176, 2009.

Sitch, S., Brovkin, V., von Bloh, W., van Vuuren, D., Eickhout, B., and Ganopolski A.: Impacts of future land cover changes on atmospheric $\mathrm{CO}_{2}$ and climate, Global Biogeochem. Cy., 19, GB2013, doi:10.1029/2004GB002311, 2005.

Sokolov, A. P., Kicklighter, D. W., Melillo, J. M., Felzer, B. S., Schlosser, C. A., and Cronin, T. W.: Consequences of Considering Carbon-Nitrogen Interactions on the Feedbacks between Climate and the Terrestrial Carbon Cycle, J. Climate, 21, 37763796, 2008.

Taylor, K. E., Stouffer, R. J., and Meehl, G. A.: An overview of CMIP5 and the experiment design, B. Am. Meteorol. Soc., 93, 485-498, 2012.

Thornton, P. E., Lamarque, J. F., Rosenbloom, N. A., and Mahowald, N. M.: Influence of carbon-nitrogen cycle coupling on land model response to $\mathrm{CO}_{2}$ fertilization and climate variability, Global Biogeochem. Cy., 21, GB4018, doi:10.1029/2006GB002868, 2007.

Vitousek, P. M., Porder, S., Houlton, B. Z., and Chadwick, O. A.: Terrestrial phosphorus limitation: mechanisms, implications, and nitrogen-phosphorus interactions, Ecol. Appl., 20, 5-15, doi:10.1890/08-0127.1, 2010.

Wang, Y. P., Law, R. M., and Pak, B.: A global model of carbon, nitrogen and phosphorus cycles for the terrestrial biosphere, Biogeosciences, 7, 2261-2282, doi:10.5194/bg-7-2261-2010, 2010.

Wang, Y. P., Kowalczyk, E., Leuning, R., Abramowitz, G., Raupach, M. R., Pak, B., van Gorsel, E., and Luhar, A.: Diagnosing errors in a land surface model (CABLE) in the time and frequency domains, J. Geophys. Res., 116, G01034, doi:10.1029/2010JG001385, 2011.

Wang, Y. P., Lu, X. J., Wright, I. J., Dai, Y. J., Rayner, P. J., and Reich, P. B.: Correlations among leaf traits provide a significant constraint on the estimate of global gross primary production. Geophys. Res. Lett., 39, L19405, doi:10.1029/2012GL053461, 2012.

Yang, X., Richardson, T. K., and Jain, A. K.: Contributions of secondary forest and nitrogen dynamics to terrestrial carbon uptake, Biogeosciences, 7, 3041-3050, doi:10.5194/bg-7-30412010, 2010. 
Zaehle, S., Friedlingstein, P., and Friend, A. D.: Terrestrial nitrogen feedbacks may accelerate future climate change, Geophys. Res. Lett., 37, L01401, doi:10.1029/2009GL041345, 2010.

Zhang, Q., Wang, Y. P., Pitman, A. J., and Dai, Y. J.: Limitations of nitrogen and phosphorous on the terrestrial carbon uptake in the 20th century, Geophys. Res. Lett., 38, L22701, doi:10.1029/2011GL049244, 2011.
Zhou, L., Dickinson, R. E., Tian, Y., Fang, J., Li, Q., Kaufman, R. K., Tucker, C. J., and Myneni, R. B.: Evidence for a significant urbanization effect on climate in China, P. Natl. Acad. Sci. USA, 101, 9540-9544, doi:10.1073/pnas.0400357101, 2004. 